\title{
ROZPACZ JAKO ŻYCIE W ŚMIERCI W MYŚLI SØRENA KIERKEGAARDA ${ }^{1}$
}

Rozpacz jest wiecznym umieraniem, a przecież nie umarciem... ${ }^{2}$

By właściwie zrozumieć myśli wyrażane przez Sørena Kierkegaarda, należy odwołać się do pewnego porządku twórczego związanego z działalnością myśliciela. Ów porządek rozciąga się na dwóch osiach relacji i znaczeń: autorstwa wypowiedzi oraz kontekstu wypowiedzi. Pierwsza oś odnosi się do Kierkegaardowskiego podwójnego autorstwa, w ramach którego wyróżnia się dzieła z prawej ręki, czyli dzieła autorskie, oraz dzieła z lewej ręki, czyli dzieła pisane pod pseudonimem³ ${ }^{3}$ Druga oś odnosi się do kontekstu społeczno-kulturowo-politycznego, z którym korespondowała złożona myśl tego duńskiego filozofa. Kontekst ten ujmuje przede wszystkim zmianę ustrojową w państwie duńskim, obecność i znaczenie luterańskiego kościoła państwowego, aspekty intelektualnego przebudzenia w Danii (duńskiego

\footnotetext{
${ }^{1}$ Pracę tę dedykuję Erikowi Hongowi - w podziękowaniu za wsparcie.

2 S. Kierkegaard, Choroba na śmierć, Wydawnictwo Homini, Kraków 2008, s. 171 / Sickness Unto Death, New Jersey 1980, s. 18 (SUD, 18) / Søren Kierkegaards Skrifter (SKS) 11, 134. Przypisy podane zgodnie ze standardem Kierkegaard's Writings, Princeton University Press, New Jersey oraz Søren Kierkegaard Forskningscenter, Copenhagen.

${ }^{3}$ S. Kierkegaard, The Point of View, Princeton University Press, New Jersey 1998, s. 193 $(P O V, 193)$ / SKS 22, 36, NB11:53; S. Kierkegaard, Concluding Unscientific Postscript To The Philosophical Fragments, Princeton University Press, New Jersey 1992, s. 625-630 (CUP, 625-630) / SKS 7, 569-573; A. Szwed, Pomiędzy wolnościa a prawda egzystencji. Studium myśli Sørena Kierkegaarda, Wydawnictwo Marek Derewiecki, Kęty 1999, s. 17-25; J. Ferreira, Kierkegaard, Wiley-Blackwell, Oxford 2009, s. 10.
} 
złotego wieku) oraz znaczny wpływ heglizmu i romantyzmu na myślowe trendy w ówczesnej Danii ${ }^{4}$.

Studiując jedną z fundamentalnych kwestii egzystencjalnych Kierkegaarda, a mianowicie koncepcję rozpaczy, szczególną uwagę należy poświęcić problemowi autorstwa. Temat rozpaczy w myśli Kierkegaarda omawiany jest przede wszystkim w jego napisanej pod pseudonimem pracy pt. Choroba na śmierć, wydanej $\mathrm{w}$ roku 1849. Wspomniane dzieło znane jest polskiemu czytelnikowi jako zespolone z innym studium Kierkegaarda, Bojaźń $i$ drżenie (również napisanym pod pseudonimem). Przez długi czas te dwa teksty, Choroba na śmierć i Bojaźń i drżenie, wraz z dwutomowym Albo-albo funkcjonowały w Polsce jako rdzeń filozofii Kierkegaarda ${ }^{5}$. Takie zestawienie mogło zniekształcać całościowy obraz myśli filozofa oraz wprowadzać zamieszanie we właściwym odczytaniu powyższych prac ${ }^{6}$. Autorami wspomnianych dzieł są trzej niezależni pseudonimowi autorzy, odpowiednio: Anti-Climacus, Johannes De Silentio oraz Wiktor Eremita, którzy w różnym stopniu reprezentują poglądy samego Kierkegaarda ${ }^{7}$. Niniejsze rozważania będą dotyczyły w głównej mierze postaci Anti-Climacusa oraz podglądów przez niego wyrażonych. Kierkegaard odróżnia Anti-Climacusa od Climacusa oraz pozostałych pseudonimów poprzez przyporządkowanie temu pierwszemu zintensyfikowanej religijności ${ }^{8}$.

${ }^{4}$ B.H. Kirmmse, Kierkegaard in Golden Age Denmark, Indiana University Press, Bloomington 1990; B.H. Kirmmse, On Authority and Revolution: Kierkegaard's Road to Politics, [w:] N.J. Cappelørn, J. Stewart (red.), Kierkegaard Studies: Monograph Series, t. 1, Kierkegaard Revisited, De Gruyter, Berlin 1997, s. 261-264; J. Stewart, Kierkegaard's Relation To Hegel Reconsidered, Cambridge University Press, Cambridge 2003, s. 50-82; J. Garff, Søren Kierkegaard. A Biography, Princeton University Press, New Jersey 2005.

${ }^{5}$ Przestrzeń czasowa rozciągająca się pomiędzy poszczególnymi publikacjami to: w przypadku Albo-albo (wydanej 20 lutego 1843 roku) i pracy pt. Bojaźn $i$ drżenie (wydanej 16 października 1843 roku) niecały rok, natomiast między ostatnią rozprawą a Choroba na śmierć (wydanej 30 lipca 1849 roku) sześć lat.

${ }^{6}$ Rozwój filozofii Kierkegaarda miał miejsce przez całe jego życie i wyrażał się w „ciągłości" jego publikacji. Próby odtworzenia filozofii Kierkegaarda na podstawie poszczególnych jego prac nie dają pełnego obrazu kompleksowej myśli filozofa. Brak znajomości większego zakresu jego dzieł oraz , jakiegoś interpretacyjnego klucza”, na co zwraca Antoni Szwed w Kierkegaard $w$ Polsce, wciąż powoduje problemy hermeneutyczne (zob. A. Szwed, Kierkegaard w Polsce, [w:] tenże (red.), Aktualność Kierkegaarda, Wydawnictwo Marek Derewiecki, Kęty 2005, s. 197-201).

7 Na temat koncepcji i roli pseudonimów w korpusie Kierkegaarda zob. A. Szwed, Między wolnością a prawda egzystencji, dz. cyt., s. 17-31; John Caputo, How To Read Kierkegaard, W. W. Norton \& Company, New York 2008, s. 67-80; J. Westfall, The Kierkegaardian Author: Authorship and Performance in Kierkegaard's Literary and Dramatic Criticism, De Gruyter, Berlin 2007; S. Walsh, Living Poetically: Kierkegaard's Existential Aesthetics, Pennsylvania State University Press, Pennsylvania, s. 10-15; M. Holmes Hartshorne, Kierkegaard, Godly Deceiver: The Nature and Meaning of His Pseudonymous Writings, Columbia University Press, New York 1990; L. Mackey, Kierkegaard: A Kind of Poet, Pennsylvania State University Press, Pennsylvania 1971, s. 3-38.

8 H.V. Hong, E.H. Hong, G. Malantschuk (red.), Kierkegaard's Journals and Papers, Bloomington, 1967-1978 (JP) 6, 6431, 173 f. / 22, 127 f., NB11:204; POV, 15 / 13, 23. 
Usytuowanie Anti-Climacusa jako poprzedzającego i skontrastowanego z Climacusem ma za zadanie pokazać skontrastowanie egzystencji etycznej $\mathrm{z}$ religijną oraz wykazać różnice $\mathrm{w}$ podejściu do nauki, etyki i religii ${ }^{9}$. AntiClimacus jest autorem reprezentującym stadium religijne, jakościowo różne od stadiów estetycznego i etycznego, posługuje się zatem językiem religii. Co ważne, Anti-Climacus jest pseudonimem, z którym Kierkegaard zmagał się osobiście; na pewnym etapie pracy nad Choroba na śmierć i Wprawkami do chrześcijaństwa (drugą pracą Anti-Climacusa), Kierkegaard zamierzał opublikować pod swoim nazwiskiem i tym samym zakończyć działalność pisarską ${ }^{10}$. Ostatecznie jednak ${ }^{11}$, zdając sobie sprawę z faktu, iż sam egzystencjalnie nie reprezentuje chrześcijanina, a więc próba utożsamienia stałaby w sprzeczności z jego koncepcją prawdziwości, opublikował te prace pod pseudonimem. Choroba na śmierć, pierwsze dzieło Anty-Climacusa, jest zarówno traktatem teologicznym, charakteryzującym się natężeniem języka religijnego i zintensyfikowaną intymnością, jak również rozprawą filozoficzną. Według założeń autora, "dialektyczna algebra”, jak nazwał swoje dzieło, miała wyróżniać się między innymi wzmożoną dialektyką, koncentracją na zagadnieniu jaźni (Selvet) oraz uniwersalnością ${ }^{12}$.

Mając na uwadze pokrótce zarysowane tło Choroby na śmierć, możemy podjąć się analizy kategorii rozpaczy. Rozpacz (Fortvivlelse) jako termin po raz pierwszy pojawia się już w Dziennikach Kierkegaarda i Wczesnych pismach polemicznych ${ }^{13}$. W Chorobie na śmierć rozpacz jest przede wszystkim przedstawiona jako odnosząca się do dwóch kategorii: życia i śmierci. Te koncepty, choć do tej pory filozoficznie rozumiane jako przeciwstawne ${ }^{14}$, u Kierkegaarda przyjmują wyjątkową postać oraz zyskują specyficzne relacje. Śmierć staje się pewną sferą życia, zaś szczególny sposób życia zyskuje wymiar śmierci. To swoiste przenikanie się sfery śmierci i życia związane jest z egzystencjalną

${ }^{9}$ Na temat Kierkegaarda krytyki Heglowskiego przekształcenia religii w filozofię, a filozofii w „naukę” zob. A. Szwed, Rozum wobec chrześcijańskiego Objawienia, Wydawnictwo Marek Derewiecki, Kęty 2011. O roli Climacusa w polemice z Heglem na temat etyki i moralności zob. J. Stewart, Kierkegaard's Relation to Hegel Reconsidered, dz. cyt., s. 515-523.

${ }^{10}$ JP 6, 6517 / 22, 321, NB 13:78.

11 Decyzję o publikacji dzieła pod pseudonimem podją trzy tygodnie przed ostatecznym dostarczeniem manuskryptu do drukarza: JP 6, 6416 / 22, 70, NB 11:123. Zob. także H.V. Hong, E.H. Hong, Historical introduction, [w:] SUD, XVII.

12 JP 6, 6137 / 20, 365, NB 4;160a.

13 S. Kierkegaard, Early Polemical Writings, Princeton University Press, New Jersey 1990, s. 67-68 (EPW, 67-68) / 1, 23; Pap. II A 648 / 18, 92, FF 80.

${ }^{14}$ Epikurejskie ufundowanie rozumienia konceptów: kiedy jest śmierć, nie ma życia, i analogicznie, kiedy nie ma śmierci jest życie, spotyka się z judeochrześcijańskim rozumieniem życia i śmierci, gdzie śmierć jest pewną kontynuacją życia. Zob. S. Kierkegaard, Okruchy filozoficzne; Chwila, Państwowe Wydawnictwo Naukowe, Warszawa 1988, s. 116; S. Kierkegaard, Philosophical Fragments, Princeton University Press, New Jersey 1985, s. 95 (PF, 95) / 4, 292. 
perspektywą rozróżniającą stadium estetyczno-etyczne od religijnego. Anti-Climacus pisze:

Gdyż, mówiąc po ludzku, śmierć jest rzeczą ostateczną i, mówiąc po ludzku, nadzieja istnieje, póki istnieje życie. Ale, rozumując po chrześcijańsku, śmierć nie jest czymś ostatecznym, jest tylko drobnym zdarzeniem w przebiegu całości, to znaczy życia wiecznego, i rozumując po chrześcijańsku, w śmierci jest nieskończenie więcej nadziei niż wtedy, kiedy po ludzku mówimy, że istnieje jeszcze życie, a nawet życie w pełni zdrowia i si1 ${ }^{15}$.

Rozumując po chrześcijańsku, śmierć biologiczna nie jest czymś ostatecznym, ponieważ z jednej strony śmierć jest stanem trwającym po śmierci biologicznej, z drugiej zaś zarówno stanem, jak i procesem trwającym równolegle podczas życia biologicznego. Prawdziwa śmierć to śmierć ducha, którą AntiClimacus nazywa rozpaczą, czyli chorobą na śmierć. Rozpacz jest umieraniem za życia, czyli życiem w śmierci.

\section{Struktura rozpaczy}

Rozpacz jest kategorią antropologiczną odnoszącą się do struktury człowieka. Dotyczy ona przede wszystkim jaźni (Selvet) i ducha (Aand). W sensie strukturalnym rozpacz jest dysfunkcją, a w konsekwencji rozpadem ducha i jaźni. Jaźń jest pewną konstrukcją, której fundamentem jest kategoria stosunku. Anti-Climacus pisze:

Człowiek jest duchem, lecz czym jest duch? Duch jest jaźnią. Ale czym jest jaźń? Jaźń jest stosunkiem, który ustosunkowuje się do samego siebie lub jest tym w stosunku, co ustosunkowuje się do samego siebie; jaźń nie jest stosunkiem, lecz jest tym, że stosunek ustosunkowuje się do samego siebie. Człowiek jest syntezą skończoności i nieskończoności, tego co czasowe i tego co wieczne, wolności i konieczności, krótko: syntezą. Synteza jest stosunkiem między dwoma ${ }^{16}$.

Zbyt raptowna koncentracja na rozróżnieniu pomiędzy ,jaźnią jako stosunkiem”, a jaźnią jako „tym w stosunku, co ustosunkowuje się do samego siebie", powoduje pominięcie w powyższym cytacie dwóch ważnych szczegółów. Po pierwsze, rzadko zwraca się uwagę na fakt, iż Anti-Climacus podaje dwie definicje człowieka. $W$ ramach pierwszej definicji człowiek jest duchem/jaźnią, zaś jego strukturę precyzuje kategoria stosunku (Forhold). W drugiej definicji człowiek jest syntezą, czyli połączeniem dwóch czynników będących przeciwstawnymi kategoriami (nieskończoność i skończoność, doczesność i wieczność, wolność i konieczność). Po drugie, w początkowym

${ }^{15}$ S. Kierkegaard, Choroba na śmierć, dz. cyt., s. 162 / SUD, 7f / 11, 124.

16 Tamże. Przytoczone tłumaczenie z: A. Szwed, Pomiędzy wolnością a prawda egzystencji..., dz. cyt., s. 35. 
fragmencie powyższego cytatu brakuje pewnego logicznego uzupełnienia. Anti-Climacus pisze, iż jaźń jest stosunkiem, przy czym nie podaje składowych tego stosunku, natomiast $w$ drugiej definicji podaje dwa czynniki syntezy (pary przeciwstawnych kategorii). W domyśle, biorąc pod uwagę drugą definicję człowieka ${ }^{17}$, należałoby przyjąć, iż składowym(i) stosunku, który ustosunkowuje się do samego siebie, jest potencjalne residuum jaźni, zalążek podmiotu ${ }^{18}$. Ów zalążek podmiotu może być:

nagim abstrakcyjnym $j a^{19}$ [nøgne, abstrakte Selv - przyp. W.K.], które jest pierwotną formą nieskończonej osobowości i czynnikiem popychającym $\mathrm{w}$ całym tym procesie, w którym osobowość akceptuje nieskończenie swoją prawdziwą istotę wraz ze wszystkimi trudnościami i korzyściami ${ }^{20}$.

Choć Kierkegaard nie doprecyzowuje ontologicznego i genetycznego statusu jaźni, to na podstawie całościowej analizy dzieła możemy stwierdzić, że z jednej strony jaźń jest dana jako ukonstytuowana przez Boga, z drugiej strony jaźń wytwarza się $\mathrm{w}$ ramach procesu narastania refleksji ${ }^{21}$.

Struktura jaźni jest ufundowana na narastającej intensyfikacji kolejnych ustosunkowań jaźni do siebie samej, zaś jej umocowanie może mieć miejsce

${ }^{17}$ Choć pierwsza definicja człowieka („Człowiek jest duchem. Duch jest jaźnią”) nie podaje czynników relacji, to analizując strukturę przedstawiania człowieka w drugiej definicji („Człowiek jest syntezą"), warto zauważyć, iż obie zbudowane są na typowo heglowskich pojęciach. Kierkegaard przenosi definicję heglowskiego ducha wykuwającego się w ruchu przeciwstawnym i wynikowym tezy, antytezy i syntezy na ducha jednostkowego, rozumiejąc syntezę jako niebędącą zniesieniem (Mediation - duński oryginał, „zapośredniczenie” - przeł. A. Szwed; zob. S. Kierkegaard, Pojęcie lęku: proste rozważania o charakterze psychologicznym, odniesione do dogmatycznego problemu grzechu pierworodnego autorstwa Vigiliusa Haufniensisa, Wydawnictwo Marek Derewiecki, Kęty 2000, s. 17-18 / The Concept of Anxiety, New Jersey, 1980, s. 11 (CA, 11) / 4, 319.). Zob. S. Walsh, Kierkegaard. Thinking Christianly in an Existential Mode, Oxford University Press, 2009, s. 97 oraz M.C. Taylor, Jorneys to Selfhood: Hegel and Kierkegaard, Fordham University Press, Berkeley 2000, s. 168-171.

18 A.B. Come w Kierkegaard as Humanist: Discovering My Self, rozbierając na czynniki pierwsze strukturę jaźni, nie dostrzega powyższego rozróżnienia na dwie definicje. Zakłada implicite identyczność dwóch definicji, wychodząc z założenia, że stosunek jest syntezą i odwrotnie (McGill-Queen's Press, Montreal 1995, s. 8). W tej kwestii pozostaję w opozycji. Twierdzę, że jaźń nie jest syntezą, czyli relacją, ale syntezą w relacji.

${ }^{19}$ Podaje „jaźń" i „ja” wymiennie.

${ }^{20}$ S. Kierkegaard, Choroba na śmierć, dz. cyt., s. 212 / SUD, 55 / 11, 170.

21 Tamże, s. 196 / SUD, 16 / 11, 156. Jeżeli jakieś dane residuum podmiotowości ustosunkowuje się do samego siebie, czyli zwraca się do samego siebie, następuje to przede wszystkim $\mathrm{w}$ wyniku ujęcia siebie $\mathrm{w}$ zasięgu swojego postrzeżenia. Jeżeli zaś owo dostrzeżenie się / ujęcie się w zasięgu swojego postrzeżenia zwraca się do siebie, oznacza to, iż podmiot nie tylko „pasywnie” jest świadomy siebie. Oznacza to przede wszystkim, iż podmiot staje się świadomy faktu nie tylko swojego istnienia, ale staje się świadomy własnej świadomości. Dlatego, co mówi Anti-Climacus, „jaźń (...) jest zjawiskiem ustosunkowania się stosunku do samego siebie" (S. Kierkegaard, Choroba na śmierć, dz. cyt., s. 166 / SUD, 13 / 11, 129). Zobacz także: S. Kierkegaard, Albo, albo, t. 2, Wydawnictwo AMBER, Warszawa 1982, s. 352 / Either-Or, New Jersey 1987, s. 259 (EOII, 259) / SKS, 3, 246-247. 
bądź w sobie, bądź w „innym” (Andet) ${ }^{22}$. To właśnie relacyjna struktura jaźni jest materią rozpaczy. Rozpacz jest zakłóceniem, wypaczeniem właściwego stosunku (Misforhold) w ramach konstrukcji i funkcjonowania jaźni²3. Rozpacz $\mathrm{z}$ jednej strony jest stanem jaźni, $\mathrm{z}$ drugiej strony posiada strukturę podobną do jaźni, ponieważ zakrzywiając właściwe ustosunkowanie, generuje kolejne ustosunkowania. Zakłócone ustosunkowanie, będące wynikiem rozpaczy, jest zakłóceniem stosunku, który odnosi się do siebie i został ustanowiony przez to, co „inne”. W związku z powyższym, ten zakłócony stosunek w stosunku do siebie odzwierciedla stosunek do tego, co ów stosunek ustanowiło. Rozpacz wpływa na kondycję człowieka jako jednostki, ale też na ustosunkowanie się jednostki do „Mocy” (den Magt), która zakłada cały stosunek. Wykorzenienie rozpaczy Anti-Climacus nazywa przejrzystym oparciem się na "Mocy", stanem zbawienia albo po prostu byciem prawdziwym chrześcijaninem.

\section{Genetyka rozpaczy}

Rozpacz związana jest z kategorią możliwości odniesioną do struktury ludzkiej jaźni. Być człowiekiem to posiadać możliwość rozpaczy, czyli duchową sferę człowieka ${ }^{24}$, którą Anti-Climacus łączy z odpowiedzialnością i wolnością ${ }^{25}$. Rozpacz jest wynikiem możliwości wzięcia przez człowieka odpowiedzialności za dokonane wybory. Dlatego rozpacz jako przyczyna i jako konsekwencja jest stanem duszy, ale też jest jej stawaniem się, gdyż rozpacz nie tylko jest, ale się staje.

Rozpacz objawia się w trzech formach. Pierwsza wynika z faktu nieświadomości swojej osobowości; Anti-Climacus nazywa ją rozpaczą niewłaściwą. To słabo rozwinięta świadomościowo jaźńn ${ }^{26}$, która nie ma swojego umocowania ani w sobie, ani w „innym”. O drugiej formie rozpaczy mówimy, gdy odnosimy się do jaźni, która założyła samą siebie. W tym sensie rozpacz związa-

22 Tamże, s. 167 / SUD, 13f. / 11, 129. „Taki pochodny, ustanowiony, założony stosunek jest ludzką jaźnią, stosunkiem, który łączy się sam ze sobą i, łącząc się z sobą, łączy się z innym [Andet - przyp. W.K.]". Duńskie Andet może oznaczać również: drugie lub kolejne.

${ }^{23}$ Jarosław Iwaszkiewicz jest niekonsekwentny w swoim tłumaczeniu. Czytając tłumaczenie tego wybitnego humanisty i porównując je z oryginałem duńskim, można mieć wrażenie, że z jednej strony Iwaszkiewicz ukwieca toporny język Kierkegaarda, z drugiej strony dokonuje pewnej interpretacji. Forhold tłumaczy albo jako połączenie, albo jako stosunek (stosunek nie zakłada od razu połączenia), Selv tłumaczy jako ,jaźn”", „osobowość” lub ,ja”, zaś Andet to raz „inny”, raz „inny czynnik”.

${ }^{24}$ S. Kierkegaard, Choroba na śmierć, dz. cyt., s. 170 / SUD, 17 / 11, 133 („Rozpacz jest określonością ducha i znajduje się w stałym odniesieniu do tego, co wieczne w człowieku”).

${ }^{25}$ Tamże, s. 169 / SUD, 16 / 11, 132.

${ }^{26}$ Na temat rozróżnienia jaźni na ,jjaźń pierwszą" (første Selv) i „głęboką" (dybere Selv) zob. S. Kierkegaard, Eighteen Upbuilding Discourses, Princeton University Press, New Jersey 1990, s. 314-320 (EUD, 314-320) / 5, 306-311. 
na jest z wewnętrznym pragnieniem „niebycia sobą, unicestwienia siebie” 27 . Trzecia forma rozpaczy związana jest z pragnieniem bycia sobą, co wynika z „niemożliwości osiągnięcia przez jaźń samą z siebie równowagi i spokoju” ${ }^{28}$, poprzedzonego ukonstytuowaniem jaźni w „innym” ${ }^{29}$. Powyższe formy rozpaczy pokazują brak pełni życia, życia toczonego "chorobą na śmierć." Jak pisze Anti-Climacus: „W rzeczywistości wcale tak nie jest, aby się umierało z tej choroby, aby ta choroba kończyła się śmiercią cielesną" ${ }^{30}$. Fakt możliwości śmierci cielesnej, która kończyłaby rozpacz życia, byłby ratunkiem z rozpaczy, czyli ratunkiem z życia w śmierci. „Przeciwnie, męką rozpaczy jest, że nie można umrzeć”31. Rozpacz jest więc „wiecznym umieraniem”32, zaś „śmierć z rozpaczy przemienia się zawsze w życie”"33. Jest ona nieustanną konsumującą się siłą wyniszczającą człowieka, która nigdy nie ustaje. Rozpacz podtrzymywana jest poprzez samą ludzką strukturę. Człowiek rozpacza z powodu swojego zrozpaczenia, a to rozpaczanie podtrzymuje i stymuluje ludzkie zrozpaczenie. Algorytmem rozpaczy jest stosunek do samego siebie. Zrozpaczenie człowieka wynika z jego chęci pozbycia się siebie. Przeciwieństwo rozpaczy wynika z prawdziwego pragnienia bycia tym, kim się jest.

Jak wynika z duchowego charakteru rozpaczy właściwego każdemu człowiekowi, rozpacz jest czymś uniwersalnym. Mimo że człowiek nie zauważa w swoim życiu rozpaczy, co może być charakterystyczne dla osoby nieświadomej siebie, to właśnie rozpacz jest nieświadomością rozpaczy ${ }^{34}$. Może się skrywać „w najgłębszym środku szczęścia” 35 wraz z kolejną egzystencjalną kategorią Kierkegaarda, lękiem ${ }^{36}$. Radość z prostego życia, przepełnionego „wdziękiem kobiecej młodości, który cały jest spokojem, harmonią i radością, jest także rozpaczą", kryjącą się pod powierzchownym odczuciem szczęścia ${ }^{37}$. Konsekwencją niedostrzegania siebie jako ducha jest nieumiejętność zdania sobie sprawy z tego, że człowiek egzystuje wobec Boga; to właśnie poprzez rozpacz człowiek może ostatecznie zdać sobie sprawę z tego faktu. Poznanie

27 S. Kierkegaard, Choroba na śmierć, dz. cyt., s. 167 / SUD, 14 / 11, 130.

28 Tamże.

29 Tamże.

30 Tamże, s. 171 / SUD, 17f. / 11, 133.

31 Tamże,

32 Tamże, s. 171 / SUD, 18 / 11, 134.

33 Tamże.

34 Tamże, s. 177 / SUD, 23 / 11, 139.

35 Tamże, s. 179 / SUD, 25 / 11, 141.

${ }^{36} \mathrm{Na}$ temat relacji pomiędzy rozpaczą i lękiem zob. W. Kaftański, The Awakening Role of Despair and Anxiety for the Existential Self, [w:] R. Kralik (ed.), In The Shadow of Kierkegaard, Central European Research Institute of Søren Kierkegaard Constantine the Philosopher University in Nitra, Slovakia) with cooperation Kierkegaard Circle, University of Toronto, Toronto-Nitra 2011, s. $167-181$.

37 S. Kierkegaard, Choroba na śmierć, dz. cyt., s. 179 / SUD, 25 / 11, 141. 
Boga jest zadaniem przeznaczonym dla człowieka, zaś rozpaczą, ale i nędzą człowieka jest to, że musi doświadczać rozpaczy, aby móc „przebić się" przez "gwar świata" 38 wypełniony „nieustannym i bezpłodnym wirem próżnych zajęć" ${ }^{\prime \prime}$, ażeby to zadanie wykonać.

\section{Rozpacz jako droga ze śmierci do życia}

Człowiek z natury nie jest świadomy swojej wieloaspektowej struktury; nie jest ona w swej złożoności samorzutnie oczywista dla naturalnie egzystującej jednostki ${ }^{40}$. Rozpacz jest tym, co zawarte w strukturze człowieka „zmusza” go do odkrywania pełni swojej egzystencji. Ten proces ma miejsce w przestrzeni ludzkiej egzystencji, którą Kierkegaard nazywa stadiami na drodze życia ${ }^{41}$. W skład tych stadiów wchodzą trzy "sfery egzystencji”: estetyczna, etyczna i religijna, które różni od siebie intensyfikacja świadomości ${ }^{42}$, stosunek między przeciwstawnymi elementami składowymi ludzkiej syntezy oraz stosunek do tego, co absolutne / ostateczne.

Estetyk jest osobowością, która posiada mniejszy stopień (auto)refleksji i wewnętrzności ${ }^{43}$ od etyka, dlatego też rozpacz mająca miejsce u estetyka ma inny wymiar niż rozpacz osoby etycznej. Rozpacz estetyka z jednej strony wynika $\mathrm{z}$ nieumiejętności życia $\mathrm{w}$ świecie pozbawionym stale zmieniających się bodźcó $\mathrm{w}^{44}$, $\mathrm{z}$ drugiej jednak strony spowodowana jest tym, że choć w pewnym sensie jest on tym, kim chce być, gdyż wydaje mu się, że jest on tym, kim chce być, "Moc” do której człowiek jest ostatecznie odniesiony, „zmusza go do pozostania osobowościa [do bycia sobą - være det Selv - przyp. W.K.], którą on nie chce byćs ${ }^{\prime \prime 5}$. Estetyk z jednej strony koncentruje się na niekoncentrowaniu się na sobie - jego uwaga skupia się na kontestacji i utrzymaniu sta-

38 Tamże, s. 181 / SUD, 27 / 11, 143.

39 Tamże.

40 Zob. A.B. Come, Kierkegaard as Humanist, dz. cyt., s. 10-12.

41 S. Kierkegaard, Stages on Life's Way, Princeton University Press, New Jersey 1988, s. 1, 476-477 (SLW, 1, 476-477) / 6, 5, 439-440.

42 S. Kierkegaard, Choroba na śmierć, dz. cyt., s. 171, s. 236-237 / SUD, 18, 79 / 11, 134, 193.

43 Rozdzielam wewnętrzność od duchowości. Wewnętrzność jest sferą, w której ma miejsce refleksja człowieka oraz „religijność A” czy „religijność sokratejska”. Wewnętrzność jest zalążkiem duchowości w sensie „religijności B”. Duchowość jest przestrzenią religijną w której człowiek odnosi się do wieczności, transcendując rzeczywistość. Zob. E.F. Mooney, On Søren Kierkegaard: Dialogue, Polemics, Lost Intimacy, and Time, Ashgate Publishing, Hampshire 2007, s. 29-31.

44 K. Toeplitz, Teoria osobowości estetycznej, [w:] A. Szwed (red.), Aktualność Kierkegaarda, dz. cyt., s. 8, s. 13-15.

45 S. Kierkegaard, Choroba na śmierć, dz. cyt., s. 174 / SUD, 20 / 11, 136. Zob. także A. Hannay, Kierkegaard and the Variety of Despair, [w:] G.D. Marino, A. Hannay, The Cambridge Companion to Kierkegaard, Cambridge University Press, Cambridge 1998, s. 331 
nu, w którym się znajduje. Z drugiej strony budząca się w nim świadomość kwestionuje jego bycie sobą na poziomie teoretycznym. W konsekwencji trwa on w rozpaczy, ponieważ nie wie, kim jest, ale i trwa w rozpaczy, ponieważ jego duchowość ${ }^{46}$, choć uśpiona, wciąż pozostaje w odniesieniu do wieczności. „Nie jesteś dzieckiem, w którym dopiero budzi się świadomość, i dlatego Twoje spojrzenie oznacza coś innego; jesteś z tego raczej zadowolony. Kochasz to, co przypadkowe" ${ }^{\prime 7}$. W innym liście do A, O równowadze między tym, co estetyczne, i tym, co etyczne, tak radca sądowy Wilhelm, główna postać Albo, Albo, przedstawia trwanie estetyka w rozpaczy:

Jeśli więc ludzie rozpaczają, to źródeł tego stanu należy doszukiwać się w nich samych, w tym, że już uprzednio byli zrozpaczeni. Różnica polega jedynie na tym, że oni o tym nie wiedzieli, ale to jest różnica o charakterze przypadkowym. Okazuje się zatem, że każdy estetyczny pogląd, dotyczący określonego trybu życia, zawiera rozpacz i że każdy, kto żyje wedle wymogów estetyki, rozpacza niezależnie od tego, czy jest swojego stanu świadom czy nie. Jeśli o tym wie, a przecież Ty zdajesz sobie z tego sprawę, wówczas nieodzowną koniecznością staje się przejście do wyższej formy istnienia ludzkiego ${ }^{48}$.

Dla estetyka niezastąpionym na drodze ku życiu staje się moment zwrotny, czyli przeskok do etapu etycznego. Rozpacz etyka związana jest z centralnym aspektem jego jaźni, czyli wyborem, a dokładnie mówiąc, z absolutnym wyborem samego siebie w skoku egzystencjalnym. I to ostatecznie ten wybór ontologicznie wyzwala etyka z estetyka. Choć estetykowi wydaje się, że koncentruje się on na swoim „ja”, co ma miejsce poprzez powierzchowne zainteresowanie się swoimi potrzebami, to właśnie etyk strukturalnie stawia „ja” jako centrum swojego świata, jako swój ostateczny telos. "Ja” staje się tym, co ostatecznie ważne / absolutne dla etyka. Pomimo jakościowej różnicy pomiędzy estetykiem a etykiem, ten drugi nie jest pozbawiony rozpaczy. Odsłania ona martwotę życia zarówno estetyka, jak i etyka. Choć Kierkegaard wprowadza rozpacz jako kategorię mającą służyć krytyce etyka świadomie nieodniesionego do tego, co Absolutne, jej kolejnym ważnym aspektem jest krytyka społeczeństwa mieszczańskiego ${ }^{49}$. Rozpacz tkwi głęboko w zadowolonej z siebie społeczności mieszczańskiej; pod pozorną harmonią i powierzchownym ładem kryje się przeciętność i sztuczność, konformizm i konsumpcjonizm $^{50}$. W Albo, albo radca sądowy Wilhelm przekonuje A do wyższości stanu etycznego nad estetycznym. Jednakże nie dostrzega nieprawdziwości życia jakie wiedzie, życia wpasowanego w społeczny konstrukt, który roz-

46 E.F. Mooney, On Søren Kierkegaard, dz. cyt., s. 29-31.

47 S. Kierkegaard, Albo, albo, dz. cyt., s. 6 / EOII, 7 / 3, 17.

48 Tamże, s. 258 / EOII, 192 / 3, 186.

49 S. Kierkegaard, Choroba na śmierć, dz. cyt., s. 196-197 / SUD, 41f. / 11, 156-157.

50 Tamże. Zob. także: R. Perkins, Kierkegaard's Critique of the "Bourgeois" State, „Inquiry An Interdisciplinary Journal of Philosophy" 1984, t. 27, s. 207-218. 
dziela role poszczególnym częściom składowym społeczeństwa, obdzierając człowieka z jego indywidualności i nie przyzwalając na nieprzystawalność, niedefiniowalność i nieredukowalność jednostki do danych ról społecznych ${ }^{51}$. Radca sądowy Wilhelm to zadowolony z siebie człowiek sukcesu, który tak pisze o sobie:

Pracuję jako radca sądowy, jestem ze swego zawodu zadowolony i sądzę, że praca ta odpowiada moim uzdolnieniom i całej mojej osobowości, wiem też, że pochłania całą moją energię. Staram się coraz bardziej doskonalić swoje kwalifikacje zawodowe, a postępując tak, czuję, że jednocześnie sam rozwijam się coraz bardziej. Kocham moją żonę i lubię moje ognisko domowe; z radością słucham śpiewu mojej żony nad kołyską... (...) Moja praca ma dla mnie sens i - przypuszczam - również w pewnej mierze dla innych, chociaż nie mogę bliżej określić wynikających stąd korzyści. (...) Taki właśnie sens ma moje życie dla mnie i dlatego mogę się czuć szczęśliwy ${ }^{52}$.

Radca sądowy Wilhelm zatraca swoją jednostkowość poprzez życie pochłonięte zmartwieniami dnia codziennego i realizację wzorców społecznych (człowieka sukcesu, przedsiębiorcy, głowy rodziny), które są mu świadomie lub podświadomie dyktowane ${ }^{53}$. Dokonuje przewartościowania wewnętrzności na rzecz szczęścia, czy poczucia zadowolenia. Anti-Climacus pokazuje, że rozpacz kryje się tam, gdzie powierzchownie tkwi szczęście. Szczęście, czy zadowolenie, nie jest kategorią duchową; to właśnie szczęście czy zadowolenie skrywa lęk i rozpacz ${ }^{54}$.

Pomijając fakt, że człowiek może stać się fantastą, a zatem zrozpaczonym, może on żyć sobie spokojnie, być człowiekiem jak każdy inny, zajmować się doczesnymi sprawami, żenić się, płodzić dzieci, być uczonym i szanowanym - i nawet się nie zauważa, że w głębszym znaczeniu tego słowa nie ma się osobowości. Na temat takich rzeczy nie robi się w świecie hałasu; gdyż osobowość to taka rzecz, o którą najmniej chodzi w świecie, i niebezpiecznie jest pokazywać, że się ją posiada. Największym niebezpieczeństwem jest stracić samego siebie, ale może to ujść niepostrzeżenie. Żadna inna strata nie przychodzi tak niepostrzeżenie; każda inna strata, ręka, noga, pięć dukatów, żona - to co innego ${ }^{55}$.

Poza przewartościowaniem wewnętrzności na rzecz szczęścia, radca sądowy Wilhelm dokonuje kolejnego przewartościowania: doznań religijnych na doznania estetyczne, co tylko pogłębia jego szczęście. Wskazuje on, że "równolegle” ze wspomnianym i opisanym wcześniej życiem szczęśliwym, „prowadzi inne, wyższego rzędu”, które sprawia, że jego szczęście

${ }^{51}$ K. Toeplitz, Kierkegaard, Wiedza Powszechna, Warszawa 1975, s. 67-70.

52 S. Kierkegaard, Albo, albo, dz. cyt., s. 442-443 / EOII, 323-324 / 4, $305 \mathrm{f}$.

53 S. Kierkegaard, Choroba na śmierć, dz. cyt., s. 188 / SUD 33f. / 11, 149 („Oglądając tłumy ludzi naokoło siebie, zajęty najrozmaitszymi sprawami świata, ucząc się, jak to jest na świecie, człowiek ten zapomina o sobie, uważa za rzecz bardzo kłopotliwą być sobą i sądzi, że znacznie łatwiej i pewniej jest być takim samym jak inni, małpować, stać się numerem wśród tłumu").

${ }^{54}$ S. Kierkegaard, Choroba na śmierć, dz. cyt., s. 177 / SUD, 23 / 11, 139

55 Tamże, s. 187 / SUD, 32f. / 11, 148. 
staje się bezgraniczne „i wtedy sztuki piękne i łaska stapiają się dla [niego - przyp. W.K.] w jedno" ${ }^{56}$. Kluczowym jest tutaj brak rozróżnienia doznania religijnego i estetycznego, które cechuje życie w stadium niereligijnym ${ }^{57}$. Brak poważnego ustosunkowania się jednostki do przestrzeni ducha owocuje, według Kierkegaarda, życiem niepełnym, prowadzonym „tanim kosztem" ${ }^{58}$. Jednostka, podejmując się wielu kompromisów, chce przeżyć życie bez większych przeciwności. Estetyzacja życia etycznego związana jest również z kryzysem wiary ${ }^{59}$. W swoim Dzienniku Kierkegaard krytykując religijny establishment stwierdza:

Tak się przedstawia relacja: czuć się dobrze w tym świecie, nie doznawać cierpienia (być) takim zadowolonym i szczęśliwym, co zostaje osiągnięte po prostu przez - trywialność, unikanie jakiejkolwiek relacji z duchem ${ }^{60}$.

\section{Śmierć jako droga wyjścia z rozpaczy}

Rozpacz ma swoje odzwierciedlenie w relacjach międzyludzkich. Przeciętność osobowości powoduje, iż jednostki legitymizują swoje postępowanie postępowaniem innych i vice versa ${ }^{61}$. Poza zainteresowaniem przede wszystkim własnym bytem, świadoma jednostka wychodzi poza siebie w stronę innych. Jednostka indywidualna (den Enkelte) wiedząc, że jest duchem, chcąc być sobą i będąc sobą, sprzeciwia się ustalonemu status quo. Za przykład takich osób Kierkegaard przytacza Sokratesa i Jezusa z Nazaretu, a ostatecznie na tym miejscu chce postawić samego siebie. W innym dziele z tego samego okresu co Choroba na śmierć, pt. Czy człowiek ma prawo dać

\section{Tamże.}

57 Tamże, s. 201-202 / SUD 45 / 11, 160. Zob. G. Pattison, Kierkegaard: Aesthetics and "The Aesthetic”, „British Journal of Aesthetics”, Vol. 31, Issue 2, Oxford 1991, s. 140-151.

58 JP 3, 2550 / 25, 400, NB30: 22 (On the other hand it would have been cruel if Christ had said to the disciples: After I am gone you will have no more to do, so get married, get yourself a nice little job and scrape some money together, be a good, decent fellow who goes to church once a week and to the Lord's Supper three times a year).

59 Czas działalności Kierkegaarda związany jest z trwającym od pewnego czasu kryzysem instytucji kościelnych w Danii czy Niemczech. W konsekwencji następuje zmiana społeczno-kulturalna, która cechuje się z jednej strony zeświecczeniem elit intelektualnych, z drugiej strony rozwojem ruchów pietystycznych. Zob. E.S. Nelson, Religious Crisis, Ethical Life, and Kierkegaard's Critique of Christendom, "Acta Kierkegaardiana”, Vol. 4, Toronto-Nitra 2009, s. $170-186$.

${ }^{60}$ JP 4, 4707 / 25, 410, NB30: 36 (Men Forholdet er dette: at have det godt $i$ denne Verden, at være uden Lidelse, saadan glad og fornøiet, naaes ganske simplement (simpelt) ved-Ubetydelighed, ved at have undgaaet ethvert Forhold til Aand - tłum. W.K.).

61 Zob. JP 3, 2684 / 26, 434, NB36: 36 (Individually, mediocre people certainly are not pushy toward each other, are guilty of no insolence; indeed, they mutually respect each other's mediocrity). 
się zabić za prawdę? ${ }^{62}$, autor o pseudonimie H.H. dokonuje podobnej do Anti-Climacusa oceny kondycji społeczeństwa, w którym przyszło mu żyćc3. H.H. stwierdza, iż to jego osobista śmierć jest odpowiedzią na potrzebę tkwiącą w sercu społeczeństwa. Widzi siebie jako męczennika, który swoją postawą, czyli oddaniem życia w celu „przebudzenia” tkwiącego w duchowym uśpieniu społeczeństwa, zmieni jego degresywną trajektorię.

Przebudzenie będzie coraz bardziej potrzebne. Ale skąd ma nadejść przebudzenie, skoro nikt nie chce podjąć prawdziwych środków przebudzenia [Opvækkelsesmiddel - przyp. W.K.], czyli oddania siebie do bycia uśmierconym za prawdę, nie w ślepym porywie, ale z chłodną precyzją i opanowaniem większym od jakiegokolwiek finansisty przeliczającego fundusze [Conjuncturerne - przyp. W.K.] $]^{64}$.

Tę myśl potwierdza wpis z Dziennika z tego okresu, w którym Kierkegaard widziałby swoją śmierć jako katalizator poważnego zainteresowania narodu jego przemyśleniami, dotyczącymi postępującej duchowej śmierci, która trawi społeczeństwo ${ }^{65}$ :

Nie, nie, nie! Być chrześcijaninem to być umęczonym. Ta przybudówka [Side-Bygning- przyp. W.K.] trylionów i kwadrylionów, którzy jedli, pili, płodzili dzieci, wznosili toasty, itd.: wszyscy radośnie w świadomości tego, że inni musieli cierpieć w strasznej agonii - ta przybudówka jest nieporozumieniem z Chrześcijańskiego punktu widzenia ${ }^{66}$.

${ }^{62}$ Tytuł orginalny dzieła to: Har et Menneske Lov til at lade sig ihjelslaae for Sandheden? (Does a Human Being Have the Right to Let himself Be Put to Death for the Truth?), zostało ono wydane 19 maja 1849 roku jako część Tvende ethisk-religieuse Smaa-Afhandlinger (Two Ethical-Religious Essays).

63 S. Kierkegaard, Without Authority, Princeton University Press, New Jersey 1997, s. 84 $(W A, 84) / 11,88$ (Humanity becomes more and more apathetic because it becomes more and more commomsensical. It becomes busier and busier because it becomes more and more wordly. The absolute goes more and more out of use).

${ }^{64}$ Tamże (Opvækkelse vil mere og mere blive fornøden. Men hoor skal Opvakkelsen komme fra, naar man ikke tør bruge det eneste sande Opvakkelsesmiddel, at lade sig slaae ihjel for Sandheden, ikke blindt stormende frem, men med roligere Besindighed, end nogen Pengemand beregner Conjuncturerne, beregnende dette Skridt - tłum. W.K.).

${ }^{65}$ Wpis do Dziennika z 1853 roku pokazuje koncepcyjne przeformułowanie męczeństwa u Kierkegaarda. W związku z tym, że kara śmierci za propagowanie własnej wiary nie była stosowana od pewnego czasu przez rząd duński, Kierkegaard ma na myśli męczeństwo związane ze społecznym ostracyzmem, ośmieszeniem oraz pominięciem. Zob. JP 2, 2046 / 25, 240, NB28: 32 (But, as mentioned, by forming a party we avoid all kinds of martyrdom. Formerly martyrdom always meant blood-martyrs; nowadays we perhaps can also think of the martyrdom of laughter. In a rational age the martyrdom of laughter is just what can be expected for wanting to be "the single individual". Fear of men dominates men; no one dares to be himself; everyone in every situation is hiding in "togetherness". And is it not true, in order if possible to help put a halt to this, is it not true that a number of us ought to get together?).

${ }^{66}$ JP 4, 4711 / 26, 22, NB31: 29 (Nei, nei, nei! Det at være Christen er at martres - denne uhyre Side-Bygning af Trillioner og Qvatrillioner, som æder drikker avler Børn klinker o: s: v: alt freidigt $i$ Betragtning af, at Andre have maatte vaande sig i de yderste Qvaler: denne Side-Bygning er, christeligt, en Misforstaaelse - tłum. W.K.). 
Kierkegaard odwołuje się do tradycji profetycznej Starego Testamentu oraz do wspomnianych postaci Jezusa z Nazaretu oraz Sokratesa. W perspektywie obywatelskiej śmierć obu jest stratą i wydarzeniem wstrząsającym częścią społeczeństwa. Dla Kierkegaarda jednak z perspektywy duchowej śmierć tych postaci jest darem. Śmierć Jezusa z Nazaretu ma przede wszystkim rolę "odkupieńczą i zbawiającą" w przestrzeni religii chrześcijańskiej ${ }^{67}$. Z drugiej strony śmierć Jezusa z Nazaretu oraz śmierć Sokratesa są manifestacjami indywidualności i niedefiniowalności tych dwóch postaci oraz ich niezależności od presji społecznej. Obaj swoją śmiercią potwierdzają prawdę, którą głoszą. Obaj też sprzeciwiają się przybraniu roli nadanej im przez tłum, czyli społecznemu konstruktowi pozbawionemu refleksji. Jezus został ukrzyżowany, ponieważ nie chciał przyjąć roli króla narodu żydowskiego oraz nie chciał się podporządkować ich wizji "tego oczekiwanego" (den Forventede):

Żydzi całą swoją uwagę poświęcili Jemu chcąc uczynić z Niego króla (...) byli tak pochłonięci ideą, że On musiał być tym oczekiwanym, że nie mogli znieść myśli, że On nie zaakceptuje zaoferowanej mu chwały ${ }^{68}$.

Martyrologia Sokratesa, choć podobna do śmierci Jezusa z Nazaretu, miała inny charakter. W wieńczącym kopenhaskie studia teologiczne dziele z 1841 roku pt. O pojęciu ironii z nieustającym odniesieniem do Sokratesa, Kierkegaard odnosi się do postaci greckiego filozofa, krytykując koncepcję społeczeństwa budowaną na Heglu. Jeśli Hegel miał rację, mówi Kierkegaard, to Sokrates jest nikim więcej jak tylko tragicznym bohaterem, zniesionym według Hegla poprzez ducha ujawniającego się w społeczeństwie. Jeśli Sokrates jest kimś więcej niż zaledwie tragicznym bohaterem, to jego wartość tkwi przede wszystkim w jego uprawnionym sprzeciwie wobec obiektywnych (abstrakcyjnych) praw stanu ateńskiego oraz $\mathrm{w}$ indywidualizmie, autoironii, subiektywności oraz uczonej niewiedzy ${ }^{69}$.

Jak zostało pokazane w tym krótkim eseju, rozpacz odnosi się przede wszystkim bezpośrednio do wewnętrznej sfery człowieka. Kierkegaardowski człowiek rozumiany jest jako jednostka $\mathrm{w}$ pewnych aspektach niezależna, gdyż potencjalnie niezależna od innych osób, trendów społeczno-intelektualnych, etc., tymczasem, zależna od swojej dynamicznej struktury,

${ }^{67} \mathrm{WA}, 64$ / 11, $69 \mathrm{f}$.

${ }^{68}$ WA, 60 / 11, 66 ([J]øderne havde fxstet hele deres Opmærksomhed paa Ham, saa de vilde giøre Ham til Konge... vare saaledes indtagne af den Idee, at Han maatte være den Forventede, at de ikke kunde udholde den Tanke, at Han ikke vilde tage mod al den tilbudne Herlighed - tłum. W.K.).

69 S. Kierkegaard, O pojęciu ironii, Wydawnictwo KR, Warszawa 1999, s. 252-264 / The Concept of Irony, New Jersey 1989, s. 259-271 (CI, 259-271) / 1, 297-308; S. Kierkegaard, Choroba na śmierć, dz. cyt., s. 284-285 / SUD, 123-124 / 14, 234-235. 
uwarunkowanej zawieszeniem pomiędzy tym, co wieczne, a tym co czasowe, odniesionej do tego, co absolutne. Rozpacz to stan, ale i proces, który trwa w jednostce przez całe życie, naznaczając ją wewnętrzną śmiercią. Kresem rozpaczy jest harmonijne połączenie ze sobą jaźni podmiotu oraz oparcie tego połączenia na „Mocy”, która ową jaźń założyła70. Rozpacz ujawnia się też w relacji międzyludzkiej, w przestrzeni społecznej. Jest kategorią diagnozy i krytyki społeczeństwa mieszczańskiego, obfitującego w „banalną codzienność"71, „brak istotnych możliwości”72, „bezduszność, determinizm i fatalizm"73. Jak zauważył Wilhelm Anz w swoim Kierkegaard on Death and Dying:

Kierkegaard nazywa [rozpacz - przyp. W.K.] chorobą na śmierć, ponieważ zakłada ona, że ludzkie życie jest w ruchu w kierunku wewnętrznej śmierci: w stronę nudy, melancholii, oraz pustego i niezadowolonego porzucenia siebie; w stronę „nie bytu” gdzie każda relacja straciła swoją prawdę - bądź poprzez wewnętrzny rozkład, rozpad czy wycofanie ${ }^{74}$.

Rozpacz jest też tym, co zmusza jednostkę do powzięcia poszukiwania siebie samego w procesie „uprzezroczystowienia” (gjennemsigtigt) 75 jednostki wobec siebie samej oraz Boga. „Uprzezroczystowienie” to inaczej spójne i harmonijne stawanie się sobą ${ }^{76}$, to proces, do którego każda jednostka jest przeznaczona ${ }^{77}$.

\section{Despair as life in death in Søren Kierkegaard's thought}

Sum mary

The author of this article outlines the background of the origins of The Sickness Unto Death and its main theme: despair. Consequently, he presents despair as built upon Kierkegaard's concept of the human self. Despair characterizes the condition of the human self. Moreover, it depicts the process of disintegration of the human self and

${ }^{70}$ S. Kierkegaard, Choroba na śmierć, dz. cyt., s. 167, 293 / SUD, 14, 131 / 11, 129, 242.

71 Tamże, s. 196 / SUD, 41 / 11, 156.

72 Tamże.

${ }^{73}$ Tamże.

${ }^{74}$ W. Anz, Kierkegaard on Death and Dying, [w:] J. Rée, J. Chamberlain (eds.), Kierkegaard: A Critical Reader, Blackwell, Oxford 1998, p. 44 (Kierkegaard calls [despair - przyp. W.K.] the sickness unto death because it implies that human life is in motion towards inner death: towards boredom, melancholy, and an empty and contentless abandonment to itself; towards a "non being" where every relationship has lost its truth-either inner deterioration or by breaking up or inverting itself).

75 S. Kierkegaard, Choroba na śmierć, dz. cyt., s. 167 / SUD, 14 / 11, 129.

76 Tamże, s. 225 / SUD, 67 / 11, 181.

77 Tamże, s. 188 / SUD, 33 / 11, 149. 
reflects the condition of a bourgeois mentality in society. The essay presents despair as the spiritual death of a single individual both for him/herself and for society, which results in the subsequent disintegration of society. Despair is a sickness that produces a life which is unfulfilled, inadequate and untrue as well as devoid of spirituality, intimacy and reflection. 
